\title{
KOMPARASI TEKNIK RESAMPLING PADA PEMODELAN REGRESI LOGISTIK BINER
}

\author{
Studi Kasus : Sikap Remaja terhadap Keperawanan di Indonesia Tahun 2017
}

\author{
(COMPARATION OF RESAMPLING METHOD IN BINARY LOGISTIC REGRESSION MODELS \\ Case Study: Youth Attitudes towards Virginity in Indonesia in 2017)
}

Rizkiani Ihfa ${ }^{1}$, Titik Harsanti $^{2}$

\author{
${ }^{1}$ Politeknik Statistika STIS \\ ${ }^{2}$ Politeknik Statistika STIS \\ Jl. Otto Iskandardinata No.64c, RT.1/RW.4, Jakarta Timur, DKI Jakarta \\ E-mail: 16.9398@stis.ac.id
}

\begin{abstract}
ABSTRAK
Ketidakseimbangan data adalah kondisi ketika data memiliki rasio yang tidak seimbang antara satu kelas dengan kelas lainnya. Ketidakseimbangan data memberikan dampak yang buruk pada hasil klasifikasi dimana kelas minoritas sering disalah klasifikasikan sebagai kelas mayoritas. Salah satu cara untuk menangani ketidakseimbangan data yaitu dengan resampling. Penelitian ini menggunakan regresi logistik biner yang didahului dengan proses resampling. Data yang digunakan adalah data sekunder yang bersumber dari SDKI tahun 2017. Hasil penelitian menunjukkan bahwa model dengan SMOTE merupakan model yang paling tepat dalam menangani ketidakseimbangan data pada sikap remaja terhadap keperawanan di Indonesia tahun 2017. Adapun variabel yang berpengaruh signifikan terhadap sikap remaja adalah jenis kelamin, diskusi masalah kesehatan reproduksi dengan teman, penyuluhan kesehatan reproduksi, penggunaan internet dan tingkat pendidikan.
\end{abstract}

Kata kunci: ketidakseimbangan data, resampling, regresi logistik biner.

\begin{abstract}
Data imbalance is a condition when data has an unbalanced ratio between one class and another. The imbalance of data has a negative impact on the classification results where the minority class is often misclassified as the majority class. One way to deal with data imbalance is resampling. This study uses binary logistic regression preceded by a resampling process. The data used is secondary data sourced from the 2017 IDHS. The results show that the SMOTE model is the most appropriate model in dealing with data imbalances on adolescent attitudes towards virginity in Indonesia in 2017. The variable that has a significant effect on adolescent attitudes is gender, discussion of reproductive health issues with friends, education on reproductive health, internet use and education levels.
\end{abstract}

Keywords: data imbalance, resampling, binary logistic regression

\section{PENDAHULUAN}

Data mining adalah sebuah disiplin ilmu yang mempelajari metode untuk mendapatkan pengetahuan atau menemukan pola dari suatu data. Secara umum, data mining adalah kegiatan pencarian (discovery) secara berulang (iterative) dan intensif yang bertujuan untuk mengekstrak pengetahuan dari kumpulan data yang tadinya tidak/belum membawa arti penting. Pengetahuan yang dimaksud dapat berupa pattern/pola, hubungan, perubahan, anomaly, struktur, rumus, aturan, ataupun model yang muncul dari data. Hasil yang didapatkan harus valid, berguna dan mudah dimengerti. Secara garis besar terdapat lima peran utama dari data mining yaitu untuk melakukan estimasi, prediksi, klasifikasi, clustering dan asosiasi (Pramana,S. Yuniarto,B., Mariyah,S., Santoso,I., Nooraeni,R, 2018). 
Klasifikasi merupakan peran utama data mining yang paling sering diterapkan dalam berbagai kasus. Klasifikasi adalah bentuk analisis data mencari sekumpulan model, pola atau fungsi yang menggambarkan dan membedakan objek data untuk dikelompokan kedalam kelas tertentu dari sejumlah kelas yang tersedia. Masalah klasifikasi sering dijumpai dalam kehidupan sehari-hari. Baik itu pengklasifikasian data pada bidang akademik, sosial, pemerintah, maupun pada bidang lainnya (Ramli, Yuniarti,.D, dan Goejantoro, 2013). Salah satu metode klasifikasi yang sering digunakan adalah regresi logistik. Analisis regresi logistik merupakan analisis statistika parametrik yang digunakan untuk menjelaskan hubungan antara variabel dependen berskala kategorik dengan satu atau lebih variabel independen (Hosmer, Lemeshow \& Sturdivant, 2013). Menurut Antipov \& Pokryshevskaya (2009), regresi logistik sangat menarik karena beberapa hal, yaitu (1) secara konsep sederhana, (2) mudah diinterpretasikan, dan (3) terbukti dapat menyediakan hasil yang akurat dan baik. Namun, regresi logistik masih memiliki kelemahan yaitu rentan terhadap underfitting/overfitting yang disebabkan oleh rasio yang tidak seimbang antara satu kelas dan kelas lainnya.

Data yang memiliki rasio tidak seimbang antara satu kelas dengan kelas lainnya dapat dikatakan sebagai imbalanced. Data mining mengartikan imbalanced sebagai kondisi ketika jumlah data pada kelas mayoritas lebih banyak dibandingkan jumlah data pada kelas minoritas (Untoro dan Buliali, 2018). Dalam kenyataannya, sebagian besar dataset klasifikasi tidak memiliki jumlah yang sama persis pada setiap kelasnya. Namun, imbalanced tidak menjadi masalah ketika perbandingan antar kelasnya tidak berbeda jauh. Imbalanced menjadi masalah ketika perbandingannya sangat besar, sehingga dapat memengaruhi hasil evaluasi. Misalnya kasus pada sikap remaja terhadap keperawanan, yang mana perbandingan antara remaja yang bersikap setuju dan tidak setuju berbeda jauh.

Laporan Survei Demografi Kesehatan Indonesia (SDKI) Remaja tahun 2017 mencatat bahwa persentase remaja yang setuju dengan pendapat "mempertahankan keperawanan sebelum menikah penting bagi perempuan" adalah sebesar 98,70 persen dan 1,30 persen remaja bersikap tidak setuju dengan pendapat tersebut. Perbandingan jumlah data pada kategori setuju dan tidak setuju merupakan contoh kasus ketidakseimbangan kelas yang perlu diatasi, karena 98,70 persen datanya terdapat di kategori setuju.

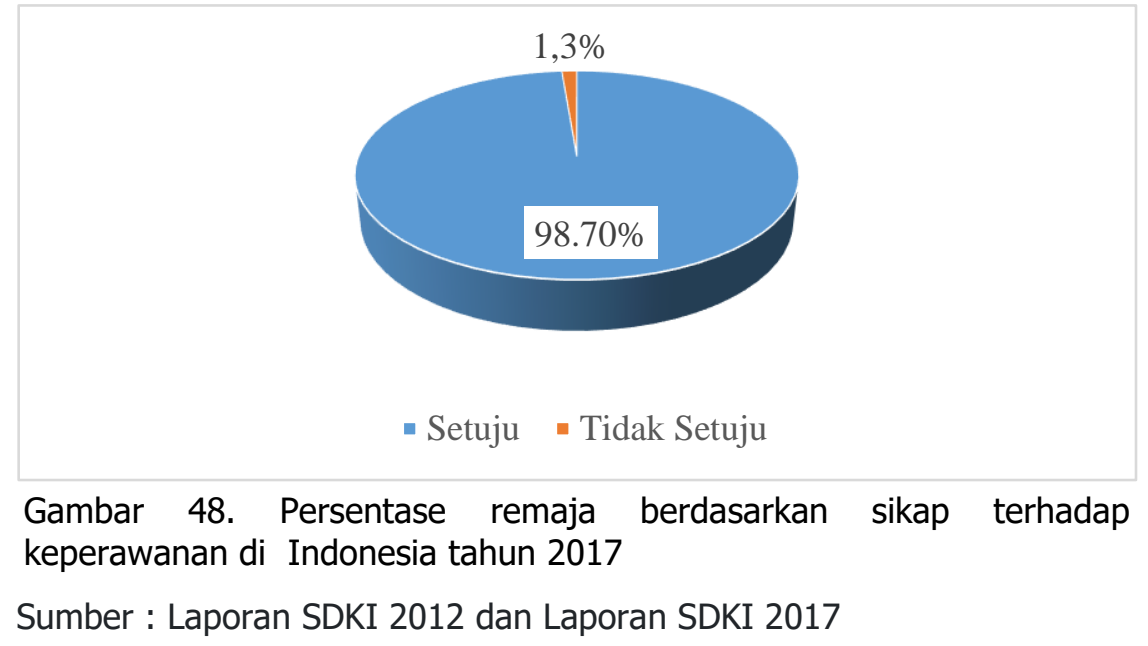

Klasifikasi pada data dengan kelas tidak seimbang merupakan masalah utama pada bidang machine learning dan data mining. Jika bekerja pada data dengan kelas tidak seimbang, hampir semua algoritma klasifikasi akan menghasilkan akurasi yang jauh lebih tinggi untuk kelas mayoritas daripada kelas minoritas. Informasi yang kaya dari kelas mayoritas mendominasi minoritas sehingga menyebabkan batas-batas keputusan yang bias dalam sistem klasifikasi (Jian et al., 2016). Terdapat tiga pendekatan untuk mengatasi masalah ketidakseimbangan kelas. Pertama yaitu dengan pendekatan level data yang berusaha menyeimbangkan distribusi data dengan cara resampling. Kedua adalah pendekatan tingkat algoritma yaitu dengan mengembangkan algoritma baru atau memodifikasi metode yang ada untuk memperhitungkan arti 
dari kelas minor. Ketiga dengan mengkombinasikan pendekatan algoritma dan pendekatan level data (Xiao, Xie, He, \& Jiang, 2012).

Dalam mengatasi masalah ketidakseimbangan kelas, penelitian ini akan menggunakan pendekatan level yaitu resampling. Pendekatan resampling dibagi menjadi tiga kategori: metode oversampling, undersampling, dan hybrid yang menggabungkan kedua pendekatan sampling (Jian, Gao \& Ao, 2016). Penelitian ini akan melakukan kajian perbandingan teknik resampling yang paling tepat digunakan untuk menangani ketidakseimbangan kelas pada kasus sikap remaja terhadap keperawanan di Indonesia tahun 2017.

\section{METODE}

Teknik resampling adalah salah satu teknik preprocessing di mana distribusi data diseimbangkan kembali untuk mengurangi efek distribusi kelas tidak seimbang dalam proses pembelajaran (Jian, Gao \& Ao, 2016). Teknik resampling secara luas digunakan untuk memecahkan masalah data yang tidak seimbang. Teknik ini dilakukan dengan mencoba menyeimbangkan data asli berdasarkan serangkaian algoritma sampling dengan menyesuaikan jumlah sampel dalam kelas yang berbeda, kemudian melatih data "seimbang" baru dengan mengadopsi algoritma klasifikasi (Syukron \& Subekti, 2018). Terdapat beberapa teknik resampling, yaitu oversampling, undersampling dan sintetis. Pada penelitian ini teknik resampling yang digunakan adalah random oversampling,random undersampling dan SMOTE. Random oversampling menyeimbangkan data dengan melakukan oversampling secara acak pada kelas minoritas. Di sisi lain, pendekatan dengan metode random undersampling secara acak memilih observasi dari kelas mayoritas untuk dieliminasi hingga data set menjadi seimbang. Selanjutnya, metode SMOTE menambah jumlah data kategori minor agar setara dengan kategori mayor dengan cara membangkitkan data buatan. Data buatan atau sintesis tersebut dibuat berdasarkan ktetangga terdekat ( $k$-nearest neighbor).

Teknik oversampling menghasilkan dataset baru yang memiliki jumlah observasi sebesar 34.304 dengan persentase kejadian setuju dan tidak setuju sebesar 50,1 persen dan 49,9 persen. Teknik undersampling menghasilkan dataset baru yang memiliki jumlah observasi 442 dengan persentase kejadian setuju dan tidak setuju sebesar 48,19 persen dan 51,81 persen. Kemudian untuk teknik SMOTE, parameter yang digunakan adalah over percentage $=200$ (menambahkan sebanyak $200 \%$ data kelas minoritas), under percentage $=100$ (memilih data pada kelas mayoritas sebanyak $100 \%$ dari total kelas minoritas yang ditambahkan) dan nilai ketetanggaan yang digunakan adalah lima. Hasilnya, untuk metode SMOTE didapatkan suatu dataset baru yang memiliki jumlah observasi sebesar 1145 dengan persentase kejadian setuju dan tidak setuju sebesar 40 persen dan 60 persen.

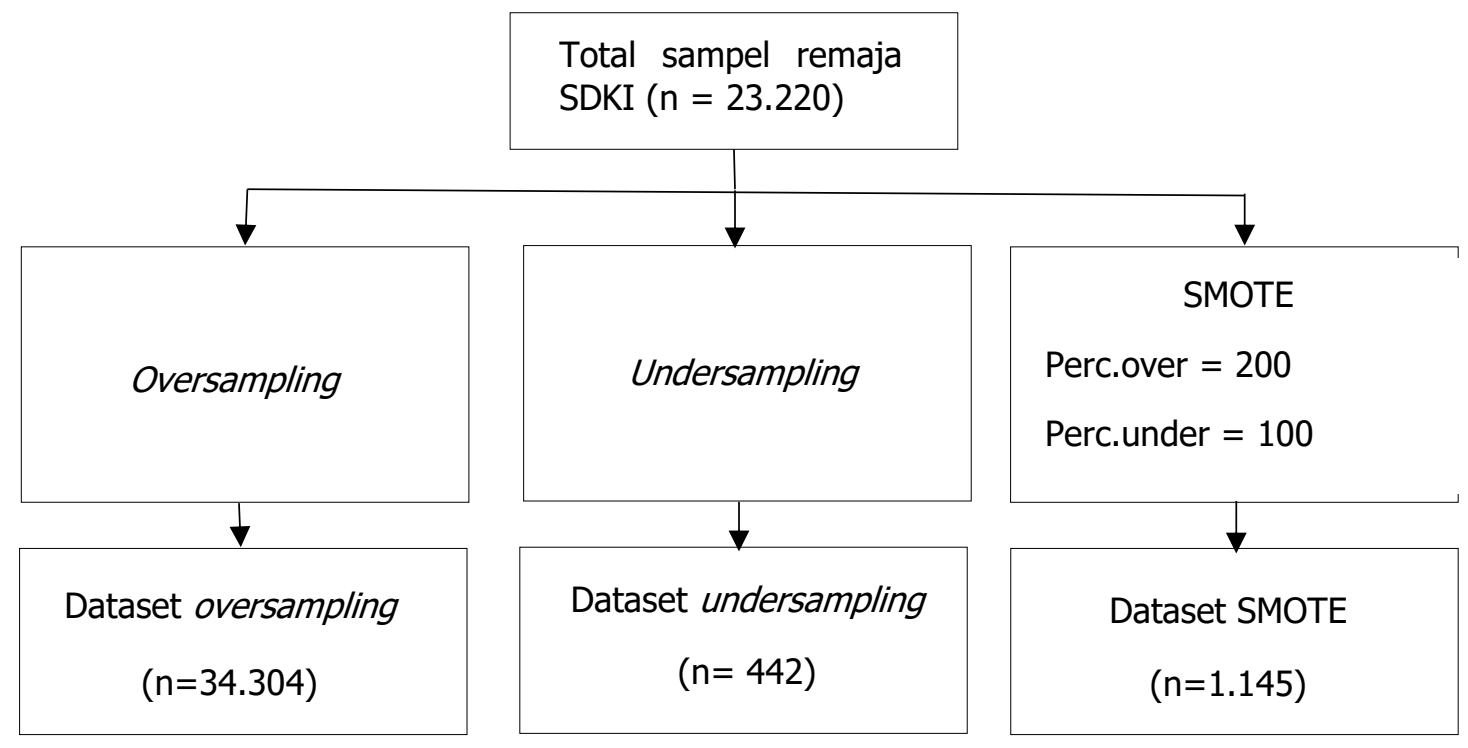


Gambar 49. Alur filter sampel

\section{HASIL DAN PEMBAHASAN}

\section{Uji Signifikansi Parameter}

\section{Uji Simultan}

Uji simultan merupakan uji parameter secara bersama-sama yang dilakukan untuk mengetahui apakah terdapat minimal satu variabel independen yang berpengaruh signifikan terhadap sikap remaja terhadap keperawanan. Hasil dari uji simultan disajikan pada Tabel 7.

Tabel 1. Hasil Uji Simultan

\section{Teknik Resampling}

(1)

\section{Oversampling}

Undersampling

\section{Deviance Nilai}

(2)

Null

Residual

Null

Residual

Null

Residual
(3)

47.555

42.407

612,16

537,74

$1.541,2$

$1.071,7$
Selisih (Nilai G)

5148

74,42

469,5

Sumber : SDKI 2017 (diolah)

Berdasarkan Tabel 1 dapat diperoleh Nilai $G$ dari perhitungan selisih antara nilai Deviance Null dan Deviance Residual. Pengujian parameter secara simultan dengan uji $G$ menghasilkan statistic uji pada data oversampling sebesar 5.148 , pada data undersampling sebesar 74,42 dan pada data SMOTE sebesar 469,5. Diketahui bahwa nilai $\chi_{(0,05 ; 7)}^{2}$ adalah 14,067 dan pada ketiga model dapat dilihat bahwa nilai uji $\mathrm{G}>\chi_{(0.05 ; 7)}^{2}$ sehingga dapat diputuskan untuk tolak $\mathrm{H}_{0}$. Artinya, pengujian parameter secara simultan pada tingkat signifikansi $5 \%$ untuk ketiga model menunjukkan bahwa minimal ada salah satu variabel independen yang memengaruhi sikap remaja terhadap keperawanan di Indonesia tahun 2017.

\section{Uji Parsial}

Uji parameter secara parsial dilakukan untuk mengetahui variabel independen yang memengaruhi sikap remaja terhadap keperawanan. Uji yang digunakan adalah Uji Wald yang hasilnya dapat dilihat dari $p$-value.

Pada model dengan oversampling dari tujuh variabel independen yang diuji terdapat lima variabel independen yang signifikan memengaruhi sikap remaja terhadap keperawanan. Lima variabel independen tersebut terdiri dari variabel jenis kelamin, diskusi masalah kesehatan reproduksi dengan teman, penggunaan internet, penyuluhan kesehatan reproduksi dan tingkat pendidikan. Model dengan undersampling terdiri dari dua variabel independen yang signifikan memengaruhi sikap remaja terhadap keperawanan yaitu, jenis kelamin dan penggunaan internet. Kemudian, model dengan SMOTE memiliki lima variabel yang memengaruhi sikap remaja terhadap keperawanan yaitu jenis kelamin, diskusi masalah kesehatan reproduksi dengan teman, penggunaan internet, penyuluhan kesehatan reproduksi dan tingkat pendidikan. 
Variabel

(1)
Kategori

(2)

\section{Oversampling}

(3)

\section{Teknik Resampling}

Undersampling

(4)

$0,0000 * *$

$0,0000 * *$

0,3686

0,1587

0,4626

$0,0000 * *$

0,4875

0,4069

0,8325

$$
1=\text { Kota }
$$

$0=$ Tidak

$$
1=Y a
$$

$0,0000 * *$

$0,0000^{* *}$

$0,0000 * *$

$0=$ Tidak

$1=\mathrm{Ya}$

$0=$

$<$ SMP/sederajat

$1=$ SMA sederajat

$2=$ Perguruan

Tinggi $\begin{array}{lll}0,0319 * * & 0,9432 & 0,0633^{*}\end{array}$

$0,0000 * * \quad 0,0944 \quad 0,0000 * *$

$0,0000 * * \quad 0,2006 \quad 0,0018 * *$

Tabel 2. Hasil uji parsial model dengan oversampling, undersampling dan SMOTE

Keterangan: *) variabel yang signifikan pada $a=10 \%, * *$ ) variabel yang signifikan pada $a=5 \%$

\section{Uji Kesesuaian Model}

Uji kesesuaian model yang digunakan pada penelitian ini adalah tabel klasifikasi dan area under ROC curve (AUC). Uji ini bertujuan untuk melihat ketepatan model dalam mengklasifikasikan sikap remaja terhadap keperawanan.

\section{Tabel Klasifikasi}

Tabel klasifikasi merupakan tabel yang menyatakan jumlah data uji hasil prediksi yang diklasifikasikan benar atau salah berdasarkan data uji hasil sebenarnya.

Tabel 3. Tabel klasifikasi model dengan oversampling

\begin{tabular}{llll} 
Observasi & Prediksi & \multicolumn{2}{c}{ Percentage Correct } \\
& Setuju & Tidak setuju \\
(1) & $(2)$ & $(3)$ & $(4)$ \\
Setuju & 4090 & 1639 & 71,39 \\
Tidak setuju & 31 & 45 & 59,21 \\
& Akurasi & & 71,23
\end{tabular}


Berdasarkan tabel 3, dapat dilihat bahwa model regresi logistik biner dengan oversampling menghasilkan nilai sensitivity sebesar 71,39 persen yang artinya model dengan oversampling berhasil mengkategorikan remaja yang bersikap setuju terhadap pendapat "mempertahankan keperawanan sebelum menikah penting bagi perempuan" sebesar 71,39 persen. Nilai specificity yang dihasilkan sebesar 59,21 persen yang artinya model berhasil mengkategorikan remaja yang bersikap tidak setuju terhadap pendapat "mempertahankan keperawanan sebelum menikah penting bagi perempuan" sebesar 59,21 persen. Nilai akurasi sebesar 71,23 persen artinya model berhasil mengklasifikasikan dengan tepat sebesar 71,23 persen.

Tabel 4. Tabel klasifikasi model dengan undersampling

\begin{tabular}{llll} 
Observasi & Prediksi & \multicolumn{2}{c}{ Perce } \\
& Setuju & Tidak setuju & \\
(1) & $(2)$ & $(3)$ & $(4)$ \\
Setuju & 2708 & 3021 & 47,27 \\
Tidak setuju & 16 & 60 & 78,94 \\
& Akurasi & & 47,68
\end{tabular}

Sumber : SDKI 2017 (diolah)

Model regresi logistik biner dengan metode undersampling memiliki nilai sensitivity sebesar 47,27 persen artinya model berhasil mengkategorikan remaja yang bersikap setuju terhadap pendapat "mempertahankan keperawanan sebelum menikah penting bagi perempuan" sebesar 47,27 persen. Nilai specificity sebesar 78,94 persen artinya model berhasil mengkategorikan remaja yang bersikap tidak setuju terhadap pendapat "mempertahankan keperawanan sebelum menikah penting bagi perempuan" sebesar 78,94 persen. Selanjutnya, model berhasil mengklasifikasikan dengan tepat sebesar 47,68 persen.

Tabel 5. Tabel klasifikasi model dengan SMOTE

\begin{tabular}{llll} 
Observasi & Prediksi & \multicolumn{2}{c}{ Percentage Correct } \\
& Setuju & Tidak setuju & \\
(1) & $(2)$ & $(3)$ & $(4)$ \\
Setuju & 3545 & 2184 & 61,87 \\
Tidak setuju & 26 & 50 & 65,78 \\
& Akurasi & & 61,93
\end{tabular}

Sumber : SDKI 2017 (diolah)

Nilai sensitivity sebesar 61,87 yang artinya model dengan SMOTE berhasil mengkategorikan remaja yang bersikap setuju terhadap pendapat "mempertahankan keperawanan sebelum menikah penting bagi perempuan" sebesar 61,87 persen, sedangkan specificity sebesar 65,78 artinya model berhasil mengkategorikan remaja yang bersikap tidak setuju terhadap pendapat "mempertahankan keperawanan sebelum menikah penting bagi perempuan" sebesar 65,78 persen. Nilai akurasi sebesar 61,93 persen menunjukkan bahwa model berhasil mengklasifikasikan dengan tepat sebesar 61,93 persen. 


\section{Area Under Curve}

Tabel 6. Nilai AUC pada ketiga model

Metode

(1)

$\begin{array}{ll}\text { Oversampling } & 0,2977 \\ \text { Undersampling } & 0,3079 \\ \text { SMOTE } & 0,6959\end{array}$

AUC

Sumber : SDKI 2017 (diolah)

Tabel 6 menunjukkan nilai AUC dari masing-masing model. Untuk memilih model yang paling tepat dapat dilakukan dengan membandingkan nilai AUC antar model. Dapat dilihat bahwa model dengan teknik resampling SMOTE memiliki nilai AUC tertinggi yaitu sebesar 0,6959. Oleh karena itu model regresi logistik biner dengan metode SMOTE dipilih sebagai model paling tepat untuk mengklasifikasikan sikap remaja terhadap keperawanan. Selanjutnya, model regresi logistik dengan metode SMOTE dipilih untuk diinterpretasikan nilai kecenderungannya.

\section{Kecenderungan Variabel-variabel yang Memengaruhi Sikap Remaja terhadap Keperawanan di Indonesia Tahun 2017}

Berdasarkan persamaan regresi logistik biner yang telah dibangun menggunakan metode SMOTE, maka dapat diperoleh tingkat kecenderungan dari tiap-tiap variabel independen terhadap sikap remaja terhadap keperawanan. Tingkat kecenderungan diperoleh dari exponensial koefisien beta $(\exp (\hat{\beta}))$. Tingkat kecenderungan setiap variabel dapat dilihat pada Tabel 7.

Variabel

(1)

\section{Kategori}

(2) $\hat{\beta}$

(3) p-value

(4)

$-2,7367$

$0=$ Laki-laki

Jenis Kelamin

Pengalaman Seksual

Diskusi masalah kesehatan
reproduksi dengan teman
Tempat tinggal

Penggunaan internet

Penyuluhan kesehatan reproduksi

Tingkat pendidikan

$$
\begin{aligned}
& 1=\text { Perempuan } \\
& 0=\text { Tidak } \\
& 1=\text { Ya } \\
& 0=\text { Tidak } \\
& 1=\text { Ya } \\
& 0=\text { Desa } \\
& 1=\text { Kota } \\
& 0=\text { Tidak } \\
& 1=\text { Ya } \\
& 0=\text { Tidak } \\
& 1=\text { Ya } \\
& 0=<\text { SMP/sederajat } \\
& 1=\text { SMA sederajat } \\
& 2=\text { Perguruan Tinggi }
\end{aligned}
$$

Tabel 7. Nilai odds ratio model SMOTE

$\begin{array}{ccc}-2,7367 & 0,0000 * * & 0,0648 \\ 1,7634 & 0,0000 * * & 5,8320 \\ 0,5004 & 0,1587 & 1,6495 \\ & & \\ -0,8241 & 0,0000^{* *} & 0,4386 \\ & & \\ -0,0336 & 0,8325 & 0,9669 \\ & & \\ 2,3851 & 0,0000 * * & 10,8598 \\ & & \\ 0,4808 & 0,0633^{*} & 1,6175 \\ & & \\ 0,9163 & 0,0000^{* *} & 2,4999 \\ 0,7871 & 0,0018 * * & 2,1969\end{array}$

8


Keterangan: $*$ ) variabel yang signifikan pada $a=10 \%, * *$ ) variabel yang signifikan pada $a=5 \%$

Remaja yang memiliki kecenderungan lebih besar untuk bersikap setuju atas pendapat pentingnya perempuan menjaga keperawanan sebelum menikah adalah remaja yang berjenis kelamin perempuan, tidak berdiskusi masalah kesehatan reproduksi dengan teman, pernah mengakses internet, pernah mengikuti penyuluhan kesehatan reproduksi dan memiliki pendidikan tertinggi Perguruan Tinggi.

\section{KESIMPULAN}

Berdasarkan nilai ketepatan klasifikasi dan AUC maka model regresi logistik biner yang terbaik untuk mengatasi masalah ketidakseimbangan kelas pada sikap remaja terhadap keperawanan adalah model yang dibangun dengan SMOTE. Berdasarkan hasil analisis regresi logitsik biner dengan teknik resampling berupa SMOTE, terdapat lima dari tujuh variabel independen yang signifikan memengaruhi sikap remaja terhadap keperawanan. Variabel-variabel tersebut terdiri dari jenis kelamin, diskusi masalah kesehatan reproduksi dengan teman, penggunaan internet, penyuluhan kesehatan reproduksi dan tingkat pendidikan. Adapun, remaja yang memiliki kecenderungan lebih besar untuk bersikap setuju atas pendapat pentingnya perempuan menjaga keperawanan sebelum menikah adalah remaja yang berjenis kelamin perempuan, tidak berdiskusi masalah kesehatan reproduksi dengan teman, pernah mengakses internet, pernah mengikuti penyuluhan kesehatan reproduksi dan memiliki pendidikan tertinggi Perguruan Tinggi.

\section{DAFTAR PUSTAKA}

Antipov, E., Elenea P. (2009). Applying CHAID for Logistic Regression Diagnostics and Classification Accuracy Improvement. Munich Personal RePEC Archive.

Hosmer, D. W., Lemeshow, S., \& Sturdivant, R. X. (2013). Applied logistic regression (3 ${ }^{\text {rd }}$ ed). New Jersey: John Wiley \& Sons, Inc.

Jian, C., Gao, J., \& Ao, Y. (2016). A New Sampling Method for Classifying Imbalanced Data Based on Support Vector Machine Ensemble. Journal Neurocomputing. 193, 115-122.

Pramana,S. Yuniarto,B., Mariyah,S., Santoso,I., Nooraeni,R. 2018. Data Mining dengan R: Konsep serta Implementasi. Bogor: In Media.

Ramli, Yuniati,D., Goejantoro, R. (2013). Perbandingan Metode Klasifikasi Regresi Logistik Dengan Jaringan Saraf Tiruan (Studi Kasus: Pemilihan Jurusan Bahasa dan IPS pada SMAN 2 Samarinda Tahun Ajaran 2011/2012). Jurnal Eksponensial 4(1)

Syukron, Akhmad \& Subekti, Agus. (2018). Penerapan Metode Random Over-Under Sampling dan Random Forest Untuk Klasifikasi Penilaian Kredit. Jurnal Informatika, 5. 175-185.

Untoro, M., \& Buliali. (2018). Penanganan imbalance class data laboratorium kesehatan dengan Majority Weighted Minority Oversampling Technique. Jurnal IImiah Teknologi Sistem Informasi 4 (1), 2018, 2329.

Xiao, J., Xie, L., He, C., \& Jiang, X. (2012). Dynamic classifier ensemble model for customer classification with imbalanced class distribution. Journal of Expert Systems with Applications, 39(3), 3668-3675. 